\title{
Schiller and Baratynsky: Truth and Eternity
}

\section{J.A. HARVIE}

Schiller's poem Resignation, written in 1784 , was popular in Russia and is frequently mentioned in the literature. In 1807 the minor poet V.S. Filomonov made a free translation, which was published in the Vestnik Evropy (European Messenger) four years later, under the title $K$ Laure (To Laura). ${ }^{1}$ It was also translated in the 1820 s by Mikhail Dmitriev. ${ }^{2}$ Among other writers it was admired by Herzen ${ }^{3}$ and Dostoevsky; there is undoubtedly an allusion to it in The Brothers Karamazov, when Ivan tells Alesha that he will return God his entrance ticket to life. ${ }^{4}$ In Turgenev's story Yakov Pasynkov the hero of the title effectively bases his life on the rejection of Schiller's conclusions, while considering Resignation to.be a splendid piece of writing. ${ }^{5}$ Tolstoy regarded the poem as one of Schiller's finest achievements. ${ }^{6}$. The German critic Setschkareff has claimed that Baratynsky's ode Istina (Truth) is 'eine Reminiszenz' of Resignation and sees it as typical of Baratynsky's work as a whole. ${ }^{7}$ Schiller's influence on Russian literature is as extensive as it is undoubted and well-documented, 8 but what follows will be mainly a consideration of possible links between Resignation and Istina.

There would probably be general agreement, both inside and outside his own country, that Evgeny Baratynsky (1800-1844), is one of the major Russian poets of the nineteenth century. ${ }^{9}$ A friend and contemporary of Pushkin, he began as a conventional elegist, but soon moved to the deeply pessimistic meditations on the human condition which characterise his best work. In these philosophic lyrics he was able in masterly fashion to unite the grand manner of the eighteenth century with the romantic pessimism of the nineteenth. His basic thesis is that the conditions of human life are such as eternally to frustrate man's deepest aspirations; and unlike his Germanophile contemporary Zhukovsky, he had relatively little faith in the possibility of transcendental compensations. With perhaps the exception of Leopardi he is probably the most gloomy poet in modern European literature. For a brief period in the $1820 \mathrm{~s}$ he was the toast of the Russian reading public, but he suffered more than most from the decline in poetic popularity following the failure of the Decembrists' Revolt in 1825.10 Paradoxically, by the time he wrote his best verse, in the 1830 s and 1840 s, he had become an anachronism for public and critics alike, so that his 
death passed almost unnoticed.11 Apart from a few, among whom however were Tolstoy and Turgenev, he was forgotten until rediscovered by the symbolists, around the turn of the century, and his reputation has been growing ever since. The appreciation in Baratynsky's poetic status that has been particularly marked since the Second World War, probably owes something to the fact that the modern world is increasingly responsive to what he has to offer, in particular to his trenchant and prophetic indictment of scientific and technological progress. 12 Though written early, Istina is a poem which bears the unmistakable stamp of his maturity; it has not, however, been much noticed by Russian critics.

Baratynsky had good cause to remember Schiller, who was so to speak responsible for his expulsion from the Pages' Corps in St. Petersburg in 1816. This institution, a boarding school for the scions of the nobility, seems more than somewhat to have resembled the military academy to which Schiller was despatched by Karl Eugen. Inspired by a reading of Schiller's Räuber, ${ }^{13}$ a group of students formed a Society of Avengers, directed at the staff of the institution. Freely extrapolating from the character of Karl Moor, Baratynsky was one of the ringleaders of the group. The Avengers' activities included the theft of a considerable sum of money and a gold snuffbox from one of the boys' parents. The robbery was quickly discovered by the authorities, and the matter even came to the attention of the emperor, Alexander I. Baratynsky was expelled from the corps in disgrace, his status as a nobleman revoked, and made to serve more than four years as a private in the army in Finland to earn the promotion to officer's rank which regained him his patent of nobility. ${ }^{14}$

Like most aristocratic Russians of his day, Baratynsky had a perfect command of French. He also knew some German, having studied the language at the Pages' Corps; and he returned to it again during what he termed his. Finnish exile. On his own admission, he never achieved any real-proficiency in German, though his characteristic modesty may have caused him to underrate his attainments. He could certainly have read Resignation in one of the existing translations; equally, his own knowledge of German would have enabled him to puzzle out anything which really interested him. Apart from this, Baratynsky's close friend the poet Del'vig, with whom he had shared a flat in St. Petersburg following his expulsion from the Pages' Corps, was of Baltic German extraction and had a complete command of the language. Accordingly, Baratynsky would have had no difficulty in obtaining an accurate commentary and rendering into Russian of the Schiller poem. ${ }^{1.5}$

Schiller's poem is considerably longer than Baratynsky's, consisting of eighteen five-line verses, as against thirteen of four lines. ${ }^{16}$ In both cases the metre is iambic. In terms of rhyme scheme and metrical structure the two poems are rather similar; the main difference being in strophe length, and the fact that Schiller generally has one short line per verse, whereas Baratynsky invariably has two. Istina scans as pentameter alternating with tetrameter, while Resignation is 
written throughout in an irregular pentameter. The German poem is rhymed $a b a a b$ and the Russian $a b a b$; in each the a rhymes are feminine and $b$ rhymes are masculine. In the German poem there seems not to be any structural significance, apart from emphasis, in the variable length of the second line of each strophe. Resignation and Istina are both written in the high style, as befits their serious subject matter. For Baratynsky, the alternating long and short lines impart a ballad-type lightness to the poem that somewhat relieves the pessimism of the contents. The poems may usefully be looked at in dramatic terms, ranging over past, present and future, though the development is not strictly chronological in either case.

Both poems begin with a statement of the human aspiration to happiness. The question is whether this aspiration can ever be realised; and, if so, how. Schiller is more assured than Baratynsky, in that he regards happiness as an inalienable right guaranteed by Nature herself. Whereas Baratynsky fully identifies himself with the first-person speaker, this is not, as will be argued later, the case for Schiller; accordingly, the German first-person speaker will figure as the lyrical hero, or simply as the hero. In the first stanza of Resignation the lyrical hero is both included and excluded in the generality of mankind, in a manner difficult to bring out in English: Auch ich. . .Auch mir ... Auch ich. But he is already repining the fact that others are happy, while he is not. His birthright has; so to speak, been forfeited, and the loss is irrevocable (first three verses)

Doch Tränen gab der kurze Lenz mir nur.

Des Lebens Mai blüht einmal und nicht wieder,

Mir hat er abgeblüht .....

Ich weiß nichts von Glückseligkeit.

Disillusionment is common to both Resignation and Istina but there is an important difference in standpoint. Under the pressure of experience, the Russian has parted with his youthful dreams; but there is no suggestion that, as with the German, he stands at the brink of death. Therefore the possibility of happiness for Schiller's lyrical hero, as he faces the silent God on the dark bridge of Eternity, can reside only in the transcendental future. However, just as disillusion is not complete for Baratynsky, so the loss of happiness is not necessarily final. Anyway, happiness has always been more of an aspiration than a reality, though the implication is that the poet had enjoyed it to some extent in his youth. Disenchantment means an earlier enchantment, as is suggested in the fourth verse by the 'blind regret for the past'. Baratynsky's current unhappiness is patent enough from the beginning, emphasised in the phrase ' $v$ pustyne bytiya' (in the wilderness of life). The noun 'pustynya', here in the locative case, is derived from the adjective 'pustoy', which means 'empty'. Taking stock in the fifth verse, the poet sees his life as 'dol'ny zhreby svoy' (my earthly fate). The adjective 'dol'ny' is archaic and Biblical, conveying the 
idea of the earth as a vale of sorrows.

Confronting Eternity, Schiller's lyrical hero demands his reward for a life of self-abnegation and asceticism. Here Eternity is endowed with many of the traditional attributes of the Christian God, expressed to some degree in Biblical language; but Eternity remains significantly silent. Eternity is seen by the hero as enthroned with the scales of justice in her hand; like God, she is regarded as capable of searching out the secret places of the human heart, of foreknowing the future and dispensing rewards and punishments in the hereafter. Suffering in this life is to be redressed by happiness in the next. Indeed, life here and now is thought of as a period of exile from man's true home, which is in the supersensible realm of the ideal, the correlate of Arcadia.

Hier öffne sich die Heimat dem Verbannten,

Hier endige des Dulders Dornenbahn.

In the words of the author of the Epistle to the Hebrews, 'here we have no continuing city, but we seek one to come'. Here and elsewhere in the poem, there are many verbal echoes of the discussion between Franz Moor and Pastor Moser on the same theme in act five scene one of the first version of Die Räuber. It is notable, however, that Schiller's hero is less than completely confident in the belief on which he has staked his life: he refers to it as 'eine frohe Sage', followed by the phrase 'spricht man' in the next verse. A whole succession of verbs in the subjunctive, including the above quotation from verse six, indicate indirect speech or thought. There is a similar area of uncertainty about Truth, identified in the same verse as 'ein Götterkind, das sie mir Wahrheit nannten' (emphasis added).

In both poems the figure of Truth appears; for Baratynsky the Istina of the title and for Schiller Wahrheit. The nouns are feminine in either case. In Russian, there are two common words for truth, 'istina' and 'pravda'; the latter also meaning 'justice'. Especially when capitalised, as here, 'Istina' may have something of the force of a Platonic absolute. ${ }^{17}$ It is probably significant that most Indo-European languages which distinguish grammatical gender make truth feminine. 18 The gender of the noun makes it easy for Schiller and Baratynsky to hypostasise Truth, as would not be the case in modern English; though this is a more notable feature of the Russian poem than the German. ${ }^{19}$ Schiller takes the personification further; in that Ewigkeit, being also a feminine noun, entails feminines Richterin and Vergelterin, the latter occurring thrice in the course of the poem. 'Istina' is a confrontment, first of all of the poet with himself, and then with Truth. ${ }^{20}$ There are accordingly only two characters; or at most three, if the two aspects of the poet's personality be considered independently. Resignation is much more complex. Besides the lyrical hero and Truth, there are several other dramatis personae, if they may be called that : Eternity, who might be identified with Deity; the World; and finally the spirit who has the last word. 
Schiller then discusses in a three-verse retrospect the basis of the belief in personal immortality on which the lyrical hero has built his life. This belief is authenticated by Truth, said to be of divine origin; an aristocratic entity or concept, clearly beyond the pale for the world at large. Truth demanded the surrender of youth and love in return for transcendental felicity. The renunciation of present happiness for the sake of future bliss is accepted by the hero by a deliberate act of will, quite different from the rejection by Baratynsky of youthful hopes and dreams, which experience had already made untenable (verse three)

Foolish art thou and all thy desires,

Was what early experience taught me,

And I have renounced for ever

The best creations of my dream.

The Baratynskian equivalent of the Schillerian hero's decision is his banishment of Truth later in the poem. For the German hero, the renunciation of Laura $^{21}$ was evidently even more painful than that of the joys of youth (verse eight)

Ich riß sie blutend aus dem wunden Herzen,

Und weinte laut, und gab sie ihr, (der Wahrheit JAH).

The recompense Truth offers for the loss of Laura has, it may be thought, a somewhat ironical ring: "Jenseits der Gräber wuchern deine Schmerzen", since 'wuchern' is the verb used to denote the obtaining of a good rate of interest.

For Baratynsky, the figure of Truth appears with a torch in her hand to offer the poet the happiness that he has missed. By cauterising his sensitive soul and damping down his passions, she will show him things as they really are (verses six and seven). 22

My torch will point the way to happiness

She promised. At my desire

I can teach thee, passionate mortal,

The consolations of dispassion.

If thou with me extinguish the ardour of thy heart, And know people for what they are,

Then perhaps, affrighted, thou wilt cease to love

Thy neighbours and thy friends.

And in verse eight happiness is equated with 'pokoy' (peace). What Truth offers is enlightment, and throughout the Russian poem words denoting light and darkness are part of the structure, as to a lesser extent are those denoting heat and cold. Thus from 'svet' (light) occurring in verse two, are derived 'svetil'nik' (torch) used thrice; 'svetilo' (luminary) verse twelve and 'prosveti' 
(enlighten) verse thirteen. Somewhat similarly the word 'zhar' (heat, fire, ardour) verse seven, is contrasted with 'khlad' (cold) verse eight, with the dispassion that Truth offers.

However, if this is happiness, it is to be achieved at a price that is higher than Baratynsky is willing to pay. The world of Truth is a kind of living death similar to that described in the later poem $\mathrm{Na}$ chto vy, dni! (Of what use are you, days!), written in 1840.23 And so the poet rejects for the present the illumination offered by Truth, on the ground that total insight into the human condition is more than the human mind can stand.24 One is reminded here of a later Schiller poem Das verschleierte Bild zu Sais 1795 where a youth, impelled by the passionate search for knowledge, insisted on lifting the veil from the statue of Truth, with the result that
Auf ewig
War seines Lebens Heiterkeit dahin, Ihn riß ein tiefer Gram zum frühen Grabe.

Truth has less to say for herself in Resignation, much of which is given over to an attack on the lyrical hero by the World for his surrender of present certainties to future hopes that are to prove illusory. In verse fifteen Schiller returns to the point of verse four; having courageously defied the ridicule of the general public, the supplicant throws himself before the throne of Eternity to claim his reward. Truth is dismissed by the World as Schatten, Schein, Wahn; and Eternity fares no better, being in verse nine denounced as 'Die Lügnerin, gedungen von Despoten', and in verse twelve she appears as

Ein Lügenbild lebendiger Gestalten,

Die Mumie der Zeit.

For the World in this poem the idea of a life beyond the grave is an illusion, a creation of the human mind based on remorse for the past and fear of the future, as is stated in verse eleven with considerable rhetorical force:

Was heißt die Zukunft, die uns Gräber decken?

Die Ewigkeit, mit der du eitel prangst?

Ehrwürdig nur, weil Hüllen sie verstecken,

Der Riesenschatten unsrer eignen Schrecken

Im hohlen Spiegel der Gewissensangst.

One is reminded of the exchange between Karl Moor and Amalia in act four scene four of the original version of Die Räuber. He has just been telling her that her love is for a lost soul, and can never be requited. Amalia says: "Nein, sie wird im Himmel belohnt. Sagt man nicht, es gebe eine bessere Welt, wo die Traurigen sich freuen, und die Liebenden sich wiedererkennen?" Karl replies: "Ja, eine Welt, wo die Schleier hinwegfallen, und die Liebe sich schröcklich wiederfindet - Ewigkeit heißt ihr Nahme - meine Amalia ist ein unglückliches 
Mädchen".

It seems likely that Schiller in Resignation is attacking, not merely the belief in personal immortality which has until the fairly recent past undergirded human existence in this world, but also religion in general and Christianity in particular, possibly anticipating the attitude he was to express in Die Götter Griechenlands a few years later. It is not just that Biblical language is used of Eternity, or that Truth is called 'ein Götterkind', though this is important; the words Gott, Götter, Ewigkeit, Richterin, Vergelterin, Retter, seem as empty of content as Wahrheit itself. In demanding his reward, the lyrical hero relies on 'ein Götterschwur' which proves to be false. The suggestion in verse ten is that the whole construct of a future life is simply man's imaginative response to the manifest malfunctioning of the world as he experiences it. Like the idea of God, the concept of personal immortality at least implies a supersensible realm of being; in Resignation the spokesman of the World is a thoroughgoing materialist who denies the possibility of any such order of existence. Some of the arguments are very weak, as for instance in verses fourteen and fifteen the fact that no corpse has ever come to life again. Moreover, even if the idea of survival is a product of man's fears of personal extinction, that still says nothing about its ontological validity one way or the other.

Despite Baratynsky's rejection of the offer of enlightenment, it is characteristic of him that neither can he make up his mind to dispense with Truth entirely. So he summons her to return to him on his deathbed (verses twelve and thirteen)

Farewell! or no. When my luminary

In the starry firmament

Shall begin to pale, and I must needs forget

All that charms the heart,

Come to me then! Open my eyes,

And enlighten my mind

So that, despising life, I may descend unrepining

To the abode of night.

And, as Setschkareff suggests, the realisation of what life is really like may make it easier for the poet to part with it. ${ }^{7}$ In the last verse the word 'bezropotno' (literally, 'without a murmur' - translated 'unrepining') chimes with 's roptan'em' (literally, 'with a murmur' - translated by turning it into a verb) from verse five. It is possible that for Baratynsky here final enlightenment means total extinction of the personality; equally possible that he envisages a future existence akin to that of the classical dwellers in the underworld. In the poem Cherep. (The Skull), written a year later, the poet applauds the fact that man's finite existence in space and time specifically excludes 'Vse istiny, izvestnye grobam' (all truths, known to the graves), otherwise life would be completely intolerable; and Smert' (Death) 1828 ends with the statement that death is the loosing of all 
riddles, the loosing of all chains'25

Schiller's spirit spokesman claims thăt man is presented with two mutually exclusive choices - Hoffnung und Genuß, rather sententiously symbolised in the form of flowers, and adds in verse seventeen:

Genieße, wer nicht glauben kann. Die Lehre

Ist ewig, wie die Welt. Wer glauben kann, entbehre.

Die Weltgeschichte ist das Weltgericht.

And in the following verse the lyrical hero is informed

Du hast gehofft, dein Lohn ist abgetragen

Dein Glaube war dein zugewognes Glück.

In other words, Faith is its own reward, and in itself constitutes happiness of a sort. The link between the Last Judgement and world history may be a further thrust at Christianity, or perhaps intended to convey a collectivist as well as an individualist emphasis. Either way, all that has been granted man is his present existence in this world, and he is advised to make the most of it, for there will be no second bite at the cherry. It is surely playing with words to suggest, as one German critic does, that Schiller has not sacrificed transcendence, he has made it immanent. ${ }^{26}$ The two notions exclude each other, and for Schiller's hero transcendence is an illusion of the same order as Truth, Eternity, and God.

While both poems are concerned with the relationship between Truth and happiness, the attitude to life and the resolution of the dialectic are by no means identical. For the German, as for the Russian, the acceptance of Truth destroys the possibility of happiness. However, Truth, banished by Baratynsky, is eventually proved by Schiller to be illusory; or perhaps, insofar as it exists at all, to be understood as 'Genuß'.27 By the time that Schiller's lyrical hero discovers the incompatibility of 'Glaube' and 'Glück', it is tragically too late for him to reconstruct his life accordingly. Resignation as it were begins where Istina leaves off - at the point of death. Baratynsky does not doubt the existence of Truth; what he says is that life lived in the full glare of Truth would be too terrible to be borne. ${ }^{28}$ Unlike Schiller's, Baratynsky's Truth does not promise man transcendental felicity, only an alternative way of coping with the problems of living in the here and now. The two poets' certainties are also different : Schiller has no doubt about the possibility of human happiness in this present world; Baratynsky is equally convinced of the existence of Truth, though the conviction is a melancholy one at best.

The major theme of Resignation is personal immortality, 29 whereas in Istina it is the possibility of happiness; it is only in the last verse that Baratynsky touches on the possibility of an afterlife. The message of the two poems is, however, the same: 'carpe diem'. But even here Baratynsky is much less confident of happiness, with or without the intervention of Truth. Having dismissed Truth, he can only say that somehow he will make his own way. Resignation is 
antireligious as Istina is not; at least not in any very direct sense, since Baratynsky's Truth does not appear to entail any specific moral or spiritual commitments. Both the tone of the German poem and the direction of the argument align Schiller with the opinion of the World and against his lyrical hero. God, if $\mathrm{He}$ exists at all, is probably to be identified with Life and Movement, as for Tolstoy's Pierre Bezukhov; 30 that is, reinterpreted in purely human terms. Nevertheless, there is a certain pathos about Resignation, which may not unfairly be read as a swan song to the simple Christian faith of Schiller's youth, when for a period he contemplated entering the ministry of the Church. While the poet clearly identifies himself with the World's rejection of the case for personal immortality, there is undoubtedly a regret for the loss of spiritual hopes and youthful faith in an eternal life which transcends the bounds of the phenomenal world. Schiller may believe his lyrical hero to be wrong, but he does not present him as either ignoble or ridiculous. Too much of himself is involved for that. He is pathetic perhaps, but he has the reader's sympathy.

While Resignation and Istina certainly have much in common, both in form and content, the similarities are not, in the absence of external evidence, sufficient to establish Baratynsky's dependence on Schiller. As has been said earlier, Baratynsky could certainly have read Resignation; whether he actually did, we shall probably never know. With one possible trivial exception, precise textual equivalence hardly exists. 31 What the Russian poet says in Istina could easily be a development of what he had been saying almost since the beginning of his career, without necessarily involving Schiller at all. Thus, in a poem written at the advanced age of nineteen, he was already lamenting that 'khladny opyt' (the cold of experience) had destroyed his youthful dreams; which in his case may have been something more than a romantic pose. Both before and after Istina Baratynsky was on occasion preaching the gospel of 'carpe diem', though with a steadily diminishing belief in the possibility of living by it. Nevertheless, the presumption is that he was probably acquainted with Resignation in some form. Even if he was not, the comparison of the two poems is of considerable interest as the response to the perennial human problem of whether or not to sacrifice the present to the future. There are also possible echoes of Schiller's Resignation in other Baratynsky poems, most notably Dve doli (Two Fates), written a few months before Istina. 32

\section{Notes}

1 Hans Bernd Harder, Schiller in Rußland, Berlin and Zürich 1969, p. 150.

2 Lidiya Ginsburg, O Lirike (On Lyric Poetry), Leningrad 1974, p. 73.

3 Edmund K. Kostka, Schiller in Russian Literature, Philadelphia 1965, p. 151.

4 Fyodor Dostoevsky, The Brothers Karamazov, tr. Constance Garnett, 
London 1949, reprint, p. 251. Here and elsewhere, reference is made to an English translation if a satisfactory translation exists.

5 Ivan Turgenev, The Diary of a Superfluous Man Etc.,tr Constance Garnett, London 1920 reprint, p. 155. Yakov Pasynkov is one of the stories translated in this volume.

6 D. Chizhevsky, "Shiller v Rossii" (Schiller in Russia), Novy Zhurnal 45 (1956), p. 129.

7 W. Setschkareff, "Zur philosophischen Lyrik Boratynskijs", Zeitschrift für slavische Philologie 19 (1947), p. 386. (The poet's name was generally spelt with an $A$ in the first syllable, both in his own time and subsequently; and this was how he himself spelt it when writing in French. However, the spelling with $O$ is etymologically correct and is still sometimes used.) Setschkareff says: "Die Ode Istina (eine Reminiszenz an die Resignation Schillers) kann als typisches Beispiel für Boratynskijs Haltung gelten. Die Allegorie der Wahrheit bietet dem Dichter die leidenschaftslose Ruhe der Erkenntnis als Lohn für die Preisgabe des echten Gefühls, der echten Freude. Für das Leben lehnt er den Tausch $a b$, doch in der Stunde des Todes solle $\mathrm{ihm}$ die Wahrheit wieder erscheinen und die Welt zeigen, wie sie ist, damit er leichter von ihr scheiden könne. Der Dichter ist sich also vollauf der traurigen Wahrheit bewußt, doch wählt er wissentlich den schönen Schein, um das Leben ertragen zu können." On its first appearance Istina was called an ode.

8 See Harder and Kostka, notes 1 and 3 above. Harder gives a detailed account of Schiller's influence on Russian literature, but covers only the period 1789 to 1814; Kostka concentrates his attention on a few major figures, including Lermontov, Belinsky, Herzen and Dostoevsky. Baratynsky is not mentioned. Charles E. Passage, in his article "The Influence of Schiller in Russia 1800-1840", American Slavic and East. European Journal 5 (1946),pp. 111-137 is concerned mainly with Zhukovsky; Baratynsky is not referred to. In his article on Schiller in Russia, see note 6 above, pp. 109-135, Chizhevsky deals with the impact of Schiller's ideas on a number of leading writers, especially Dostoevsky. There is a reference to Baratynsky on p. 118 , though this does not concern Istina. In "Shiller kak vdokhnovitel' russkikh pisateley" (Schiller as an Inspirer of Russian Writers), Russkaya Mysl'(Russian Thought) 2 (1906), pp. 1-15, Yury Veselovsky does not mention Baratynsky at all, though there are some useful comments on the German poet's influence on Zhukovsky, Pushkin and Lermontov. He says interestingly on page 4 that Zhukovsky had intended to translate Schiller's unfinished tragedy Demetrius, which deals with an episode from Russian history.

9 No satisfactory account of Baratynsky's work exists in English, just a few 
articles dealing with various aspects. The only full-length treatment is by Benjamin Dees, E.A. Baratynsky, New York 1972. This is a bad book, and cannot be recommended. The best account of Baratynsky in German is contained in the introduction by $\mathrm{H}$. Stammler to J.A. Boratynskij. Ausgewählte Gedichte, München 1948, pp. 5-27. This is followed by a translation of 32 of the poems, including Istina (Wahrheit). Also good value is Setschkareff's article for which see note 7 above. There is a substantial chapter "Einsamkeit in Leben und Werk von E.A. Baratynskij" by Ilma Rakusa in her book Studien zum Motiv der Einsamkeit in der russischen Literatur (Slavica Helvetica, 3), Lucerne 1974, pp. 142-172. In Russian, the best introduction is still Irina Semenko's chapter on the poet in her book Poety pushkinskoy pory (Poets of the Pushkin Period), Moscow 1970. More recently there is Geir Kjetsaa's monumental Evgeny Baratynsky zhizn'i tvorchestvo (Life and Work), Oslo 1973.

10 Baratynsky's main contribution to Russo-German cultural relations was his famous poem on the death of Goethe (Na smert' Gete), which featured in almost all nineteenth-century verse anthologies. According to Baratynsky, nothing living was alien to the great German poet, who encompassed the whole world with his winged thought, finding its limit only in infinity. Having made his own philosophy, art and the folk tradition, Goethe was equally at home in the peasant's hovel as in the king's palace. Particularly striking is the fourth verse: "He lived the same life as nature, understood the babbling stream, comprehended the speech of the leaves on the trees and felt the growing of the grass. The book of the stars was clear to him, and he was spoken to by the ocean wave". See also note 24 .

11 Writing in 1842, the great critic Belinsky, no friend of Baratynsky, sees the conflict between thought and feeling, between truth and faith, as fundamental to his poetry, and goes on to illustrate by quoting from Istina. See V.G. Belinsky, Polnoe sobranie sochineny (Complete Works), Vol VI, Moscow 1955, p. 474.

12 See my articles "Russia's Doomsday Poet" and "The Eclipse of the Golden Age", Forum for Modern Language Studies 9 (1973) and 12 (1976), pp. $170-181$ and $176-188$ respectively. The second is a comparative study of Baratynsky and Wordsworth.

13 Die Räuber was translated by N.N. Sandunov in 1793 and probably first staged in Russia in 1804. Seven further translations followed. Besides reading the play, Baratynsky may have seen the highly successful performance in St. Petersburg in 1814. See Harder, op. cit. p. 45; Kostka, op. cit., p. 17; and Chizhevsky, op. cit., p. 110.

14 Estimates of the effect of this disgrace on his work vary widely, but there can be little doubt that it was Finland which turned him into a major 
poet, rather than the conventional elegist that he might otherwise have remained.

15 The Russian text of Istina in transliteration is here followed by an English prose translation, which is my own. It will be appreciated that the translation extinguishes the poetry of the original, and that no translation can be completely accurate, even semantically.

\section{ISTINA}

1. O schastii s mladenchestva toskuya, Vse schast'em beden ya, Ili vovek evo ne obretu ya V pustyne bytiya? / 2. Mladye sny ot serdtsa otleteli, Ne uznayu ya svet; Nadezhd svoikh lishen ya prezhney tseli, A novoy tseli net./ 3. Bezumen ty i vse tvoi zhelan'ya - Mne pervy opyt rek; I lutschie mechty moey sozdan'ya Otvergnul ya navek/ 4. No dlya chevo dushi razuveven'e Svershilos' ne vpolne? Zachem zhe v ney slepoe sozhalen'e Zhivet o starine? / 5. Tak nekogda obdumyval s roptan'em Ya dol'ny zhreby svoy, Vdrug Istinu (to ne bylo mechtan'em) Uzrel pered soboy./ 6. 'Svetil'nik moy ukazhet put' ko schast'yu! - Veschala - Zakhochu - I, strastnovo, otradnomu besstrast'yu Tebya ya nauchu./ 7. Pushkay so mnoy ty serdtsa zhar pogubish', Puskay, uznav lyudey, Ty, mozhet byt', ispuganny, razlyubish' I blizhnikh i druzey./ 8. Ya bytiya vse prelesti razrushu, No um nastavlyu tvoy; Ya obol'yu surovym khladom dushu, No dam dushe pokoy!'/ 9. Ya trepetal, slovam ee vnimaya, I gorestno v otvet Promolvil ey: 'O gost'ya rokovaya! Pechalen tvoy privet./ 10. Svetil'nik tvoy - svetil'nik pogrebal'ny Vsekh radostey zemnykh! Tvoy mir, uvy! mogily mir pechal'ny I strashen dlya zhivykh./ 11. Net, ya ne tvoy! $v$ tvoey nauke strogoy Ya schast'ya ne naydu; Pokin' menya, koy-kak moey dorogoy Odin ya pobredu./ 12. Prosti! il' net: kogda moe svetilo Vo zvezdnoy vyshine Nachnet blednet' i vse chto serdtsu milo, Zabyt' pridetsya mne,/ 13. Yavis' togda! raskroy togda mne ochi, Moy razum prosveti, Chtob, zhizn' prezrev, ya mog v obitel' nochi Bezropotno soyti'.

\section{TRUTH}

1. Though I have longed for happiness from my youth, happiness still eludes me; and perhaps I shall never find it in the wilderness of life? I 2. My youthful dreams are fled from my heart, I cannot discern the light; I am deprived of my hopes' former aim, and have no new aim in life./ 3. Foolish art thou and all thy desires, was what early experience taught me, and I have renounced for ever the best creations of my dream./ 4. But why is the soul not completely disillusioned? Why harbours it a blind regret for the past? / 5. Once as I meditated thus and murmured against my fate, I suddenly beheld Truth before me (this was no dream)./ 6. 'My torch will point the way to happiness', she promised. 'At my desire I can teach thee, passionate mortal, the consolation of dispassion./ 
7. If thou with me extinguish the ardour of thy heart, and know people for what they are, then perhaps, affrighted, thou wilt cease to love thy neighbours and thy friends./ 8. I can destroy all the charms of life, but can instruct thy mind; I will fill thy soul with stern cold but will give thy soul peace!'/ 9. I trembled at her words and answered bitterly: 'O fateful guest! sad is thy greeting./ 10. Thy torch is the funeral torch of all the joys of earth! Alas! Thy world is the sad world of the tomb, fearsome for the living./ 11 . No, I am not thine! under thy stern tutelage I shall not find happiness; leave me, somehow I shall make my own way./ 12. Farewell! or no. When my luminary in the starry firmament shall begin to pale, and I must needs forget all that charms the heart,/ 13 . Come to me then! Open my eyes and enlighten my mind so that, despising life, I may descend unrepining to the abode of night'.

16 The text of Istina is taken from E.A. Baratynsky, Polnoe sobranie stikhotvoreny (Complete Poems). edited E.N. Kupreyanova, Leningrad 1957, pp. 97-98. The text of Resignation is from Friedrich Schiller, Sämtliche Werke, vol. III, München 1968, pp. 112-115. The later quotation from Die Räuber is from vol. I of the same edition.

17 Compare John $14: 6$, where Christ says "I am the way, the truth and the life", the Russian version has 'istina' for truth.

18 Old English is the exception here, since the word 'soth' is neuter. 'Treowth', the ancestor of the modern word, is admittedly feminine, but does not mean quite the same thing. Cognate with German 'wahr' are Latin 'verus' (true) and the Russian noun 'vera', which means 'faith', in the religious sense. Also cognate with these words is Old English 'waer' (provident, prepared) represented in the modern language by 'wary' and 'aware'. The etymology of the Russian word 'istina' is uncertain.

19 In this connection Geir Kjetsaa instances Goethe's personification of Truth as a seductive woman in the poem Zueignung. See Kjetsaa, op. cit., p. 324.

20 According to Irina Semenko, "Baratynsky's attitude to truth (istina) was always characteristically sceptical; or when absolute, he identified truth with unhappiness." Op. cit. p. 229, where she instances Istina along with other poems.

21 Critics have naturally been tempted to identify the Laura of Resignation with Charlotte von Kalb. For instance "Nur die Verwirrungen des Herzens in der Liebe zu Charlotte v. Kalb, aus denen er sich durch eine Flucht zu retten suchte, forderten ihm lyrische Bekenntnisse ab. Der Kampf ..... und Resignation spiegeln den damaligen Zustand wider" - Rudolf Haller, Geschichte der deutschen Lyrik vom Ausgang des Mittelalters bis zu 
Goethes Tod, Bern und München 1967, p. 418. On the other hand Storz denies that Resignation has any particular biographical significance, but stresses its importance for Schiller's thinking - see Gerhard Storz, Der Dichter Friedrich Schiller, Stuttgart 1959, p. 204.

To say that the poem originates in Schiller's personal experience is true but trite; and is largely irrelevant to its ideological implications. Baratynsky's Istina creates no such critical temptations. He always aimed at the maximum in philosophical generalisation, and in reworking a poem frequently eliminated even the meagre personal references of the original version. When he wrote Istina Baratynsky was serving in Finland.

22 Of this poem and Dve doli (Two Fates) E.N. Kupreyanova says: "Their theme is the tragic nature of human destiny, doomed, in the poet's view, by the eternal laws of existence, to the insoluble opposition between thought and feeling; between the delusiveness of radiant hopes and the aspirations of the heart on the one hand, and the death-dealing cold of life experience and the stern, cruel truth that is recognised therein on the other." Op. cit., p. 25.

23 Translated in the Penguin Book of Russian Verse. When Baratynsky visited Paris in 1843, he translated the poem into French, under the title Les Redites.

24 Broadly speaking, this is also the view of Michael Polyani, scientist turned philosopher, who warns that an unbridled lucidity would make knowledge itself impossible; and says that for the sake of man's humanity it is essential to preserve an element of mystery. See Michael Polyani, The Tacit Dimension, New York 1965, pp. 18-20.

25 No consistent attitude to the question of personal immortality emerges from Baratynsky's work as a whole. In Burya (The Storm) 1824 he denies the possibility outright. Otryvok (A Fragment) 1830 is a dialogue between a man and a woman, in which the latter affirms the reality of God and the afterlife while the man questions both. In his poem on Goethe (see also note 9) Baratynsky says in the fifth and final verse that if death is the end, then Goethe's tomb has vindicated his Creator, meaning that the great German poet's existence has been justified by the kind of life he lived; however, if death is not the end, then Goethe, who lived his life to the full, will be a credit to the whole human race in the world to come. The issue is therefore left completely open. In the magnificent elegy Zapustenie (The Wilderness) 1834 the individual in harmony with nature can transcend his finite existence and attain to immortality. Osen' (Autumn) 1837, arguably Baratynsky's best poem, returns the same ambiguous answer as $\mathrm{Na}$ smert' Gete (On the Death of Goethe) above. In the late poem $\mathrm{Na}$ posev lesa (On Planting a Forest) 1842 the author speaks of 
death as the dawn of eternal day. What one can say is that when Baratynsky does envisage a hereafter, this is rarely in Christian terms, and he seldom finds much joy in the prospect. That is certainly true of Istina.

26 "Dennoch hat Schiller mit diesem neuen Weltentwurf die Transzendenz nicht etwa geopfert, er hat sie nur in die Immanenz hineingezogen" Benno von Wiese, Friedrich Schiller, Stuttgart 1959, p. 233.

27 Benno von Wiese usefully points out that the word 'Genuß' was then less restrictive in meaning than is now generally the case: "Das Wort ist hier, wie auch sonst noch oft in der Sprache des 18.Jahrhunderts, positiver gemeint, als es heute meist angewandt wird. Unter Genuß versteht Schiller die Erfülltheit des irdischen Augenblicks nicht nur im sinnlichen, auch im geistigen Sinne." Op. cit., p. 233.

28 No more than Baratynsky does Schiller return a consistent answer to the problem of survival. It is not always easy to separate the chaff of rhetoric from the wheat of sense. The negative implications of the 'carpe diem' poem Melancholie, written in 1782 and addressed to Laura, are fairly obvious. Schiller's attitude in the late poem Der Pilgrim 1803 is similar to that of Resignation : the pilgrim's search for a transcendental reality in the Platonic sense is disappointed at death, when he is confronted with a pathless sea and finds that heaven and earth can never touch. On the other hand, in Die Schlacht 1782 the poet looks forward to reunion beyond the grave; and in his famous ode $A n$ die Freude 1786 the Christian idea of immortality is expressly affirmed:

Duldet mutig Millionen!

Duldet für die beß're Welt!

Droben überm Sternezelt

Wird ein großer Gott belohnen.

In the epigram Unsterblichkeit 1795 Schiller sees immortality as a merging of the individual in the universal:

Vor dem Tod erschrickst du? Du wünschest unsterblich zu leben?

Leb im Ganzen! Wenn du lange dahin bist, es bleibt.

29 This, however, is not the view of Melitta Gerhard who writes: "Daß die betrogene Jenseitshoffnung nicht der Gehalt des Gedichtes ist, sondern nur Symbol für die Forderung einer Hingabe an die Idee, die ihren Lohn in sich selbst tragen muß, das erhellt schon daraus, daß christliche und antik-mythologische Bezeichnungen: 'Götter' und 'Weltgericht', 'Vorsicht' und 'Genius' sich wahllos mischen". Schiller, Bern 1950, p. 88.

30 "Life is everything. Life is God. All is changing and moving and that change is God" - Lev Tolstoy, War and Peace, tr Constance Garnett, 
London, 1971 reprint, p. 1149.

31 In verse eight Truth tells Schiller's lyrical hero:

"Gib mir das Weib, so teuer deinem Herzen" (emphasis added); in verse twelve of Istina the poet, envisaging his own death, speaks of the impossibility of retaining anything that would make life worth living: 'vse, chto serdtsu milo' (literally, all that is dear to the heart).

32 The alternatives offered in Dve doli (Two Fates) are either 'nadezhda i volnenie' (hope and agitation) or 'beznadezhnost' i pokoy' (hopelessness and peace). To some extent, this is to stand Schiller on his head by linking hope and excitement; but hope for Baratynsky refers to the dreams and aspirations of life in this world, not to any belief in the afterlife. In a way the alternatives offered are specious, since the poet argues that whatever men choose, they will in the end be forced by fate to accept hopelessness and peace, which in practice means complete emotional disengagement. His advice is: 'Tak! dozhivayte zhizn' $v$ tishi, I beregite khlad spasitel'ny Svoey beschuvstvennoy dushi (So! live your lives out in tranquillity, and preserve the saving coldness of your inert souls.) In other words, the choice recommended here is the reverse of that advocated in Istina and in some respects more like that of Schiller's hero; but in neither Baratynsky poem is happiness more than a youthful illusion. In Dve doli the poet is as sarcastic at the expense of the 'yunoshi kipyaschie' (fiery youths) as is Schiller's World at the expense of his hero. Although translated in the Penguin Book of Russian Verse, Dve doli is poetically inferior to Istina, partly because it is over-schematic. 